\title{
Organizations' Use of Strategic Planning Tools and Techniques in the Sultanate of Oman
}

\author{
James Rajasekar $^{1} \&$ Arooj Al Raee ${ }^{2}$ \\ ${ }^{1}$ Department of Management, College of Economics and Political Science, Sultan Qaboos University, Sultanate of \\ Oman \\ ${ }^{2}$ Head of Technical Affairs, Ministry of Heritage and Culture, Sultanate of Oman \\ Correspondence: James Rajasekar, Department of Management, College of Economics and Political Science, \\ Sultan Qaboos University, Muscat, Sultanate of Oman. E-mail: raja@squ.edu.om
}

Received: December 24, 2013

Accepted: January 7, 2014

Online Published: February 23, 2014

doi:10.5539/ibr.v7n3p159

URL: http://dx.doi.org/10.5539/ibr.v7n3p159

\begin{abstract}
This study on the use of strategic planning tools and techniques in the Sultanate of Oman aims to contribute to the research on strategic planning processes. Currently, only a few research studies have been conducted on strategic planning in developing countries, especially in the Middle East. Almost no evidence of such research exists to understand the extent of the use of strategic planning tools and techniques in the Sultanate of Oman. The study used a questionnaire to ask about 14 strategic planning tools and techniques. Twenty organizations in Oman that have a written strategic plan comprised the sample population. The data were collected from heads of departments and sections, directors, managers, and advisors directly involved in the strategic planning process. The analysis shows that the most commonly used strategic planning tools employed by organizations in Oman are benchmarking, followed by stakeholders analysis and then strengths, weaknesses, opportunities, and threats (SWOT) analysis, while the Delphi technique, experience curve, Porter's five forces, and what-if analysis techniques were the least commonly used. Considering the segmentation of organizations, one can see that the financial sector and business groups use the tools most frequently whereas the single- and family-ownership groups have limited use of strategic planning tools. On average, almost $30 \%$ of the organizations in Oman never or very rarely uses strategic planning tools. This paper provides an understanding of strategic planning in Oman and supplies the missing links in the previous studies conducted on strategic planning.
\end{abstract}

Keywords: strategic planning, Sultanate of Oman, planning tools, competition, planning concepts

\section{Introduction}

Strategic management has been studied by a number of scholars from various perspectives and using approaches through several conceptual models (Urwick, 1956; Cyert \& March, 1956; March \& Simon, 1959; Ansoff, 1965, 1969; Hofer \& Schendel, 1978; Bourgeois, 1880, 1984; Olsen \& Eadie, 1982; Bracker \& Pearson, 1986; Webster, Reif, \& Bracker, 1989; Hart, 1992; De Wit \& Meyer, 1998; Porter, 1983, 2008). Defined broadly, strategic planning processes emphasize "the execution of plans produced through comprehensive analysis and systematic procedure" (Hart, 1992). The eventual objective of strategic planning is to put the organization in a positive position by enabling it to act proactively and to close the gaps between the organization's current situation and future expectations (Gooderham, 1998). Businesses are facing constant growth and rapid changes in their environments. This has increased the need for strategic planning, which is a phenomenon growing not only in Western countries but also in other countries, including those in the Arabian Gulf.

Strategic planning was initiated in the mid-1950s, flourished through the 1960s and 1970s, and further matured in the 1980s (Webster, Reif, \& Bracker, 1989). Despite a few exceptions, strategic management theorists have suggested that strategic planning is an important instrument for an organization's success (Rhyne, 1986). Thus, several reviews have found a modest but positive relationship between strategic planning and performance (Sarason \& Tegarden, 2003; Glaister, Dincer, Tatoglu, Demirbag, \& Zaim, 2008). Strategic planning tools and techniques are considered important in the strategic management process (Aldehayyat, Al Khattab, \& Anchor, 2011). Studies to understand strategic planning in some detail have been carried out for more than 30 years. While the majority of research on the strategic planning concepts and techniques has been conducted in developed countries, limited research has been done in developing countries, particularly in Arab countries (Elbanna, 2008). 
There exists almost no evidence of previous research investigating the extent of the use of planning tools and techniques in the Sultanate of Oman.

Considering the given literature review and bearing in mind that the results of studies from one region might not apply to other regions, local management practices should be examined (Tung \& Aycan, 2008). Though some studies have been carried out in particular Arabian countries (Yusuf \& Saffu, 2009; Ghamadi, 2005), there is still little research on strategic planning in this region. Hence, this paper attempts to fill this gap by providing insight into the tools and techniques used in the Sultanate of Oman.

\section{Literature Review}

The history of strategic planning begins in the military. According to Webster's New World Dictionary, strategy is "the science of planning and directing large-scale military operations, of maneuvering forces into the most advantageous position prior to actual engagement with the enemy." Taking its name and roots from the military model, early models of formal strategic planning "reflected the hierarchical values and linear systems of traditional organizations. Undertaken by elite planning function at the top of the organization, its structure was highly vertical and time-bound. A certain period would be set aside to analyze the situation and decide on a course of action. This would result in a formal document. Once this was done, the actual work of implementation - which was considered a separate, discrete process - could begin" (Wall \& Wall, 1995). Planning is needed where judgments regarding future status require various interconnected decisions. Planning is a formalized procedure to produce an articulated result in the form of an integrated system of decisions. Thoughts on and efforts to manage the future are significant components of planning (Mintzberg, 1994).

Strategic planning is a complex and ongoing process of organizational change. Many definitions of strategic planning exist, and a number of variable methods and tools can be utilized to accomplish strategic planning. Most descriptions of strategic planning are focused on aligning the organization's goals with the environment anticipated for the future. According to Olsen and Eadie (1982), strategic planning is a disciplined effort to make essential decisions and actions that shape and guide what an organization is, what it does, and why it acts the way it does.

Broadly speaking, one major difference between conventional planning and strategic planning is that, to attain results, conventional planning looks at problems based on current understanding or an outside-in mind-set (Rowley, 1997). In contrast, strategic management is concerned with broader directions and longer term aims of a business. It is intended to exploit the opportunities of tomorrow and is not concerned only with the general management of day-to-day activities. Every part of the organization has a participatory role in the strategy, including people, finances, and the environment. A formal strategic plan is one that uses clear systematic procedures to increase the involvement of those who might affect or be affected by the plan. The strategic plan must be written and focused on the long term (Bracker \& Pearson, 1986).

Strategic planning has multiple components. It generally includes elements such as establishing a vision and mission for the organization, scanning the external environment, assessing internal capabilities, and creating objectives, goals, performance measures, priorities, and implementation plans. Implementation addresses details related to how the organization's financial resources, human resources, information, and reward systems, along with its structure and culture, will be changed in the near term to achieve long-term strategic goals (Webster et al., 1989; Bourgeois, 1984; Hill \& Jones, 1995; Roush \& Ball, 1980; Campbell \& Garnett, 1989; Galbraith \& Kazanjian, 1986).

Although individual definitions of strategy vary among authors, theorists have traditionally considered planning as a crucial part of organizational strategy.

\subsection{Study and Research on Strategic Planning}

The study of strategic planning is a relatively recent phenomenon that has generated significance in organizations around the world. Though its foundation dates back to the early twentieth century, most of the research originates in Western countries as most of the development in strategy is a result of the high growth rate of industrialization in Europe, America, and Japan. Industrialist Taylor contributed to the earliest research on the subject (Taylor, 1911). Fayol put his efforts into formalizing the approach in which organizations administer future organizational activities (Fayol, 1916). In contrast, Urwick (1956) concentrated on the output and efficiency of workers by separating particular organizational functions.

Nevertheless, actual strategy studies were not published until the late 1950s. Studies were available during times of sustained economic growth and great increases in wealth in the West. Writers like Ansoff started to develop corporate strategy concepts that continued to develop throughout the 1970s (Ansoff, 1965, 1969). Though the 
'evolutionary' school was established on the research carried out by Cyert and March (1956) and March and Simon (1959), it was not until the mid-1980s and early 1990s that the complexity of strategic management was better understood (Webster et al., 1989). However, most strategic management theorists have suggested that strategic planning is an important instrument for management purposes (Rhyne, 1986).

\subsection{Importance of Environment Context in the Organization}

There is a link between the environmental contexts in which an organization exists and it influences the organization's approach to dealing with and developing its strategic processes and methodology (Bourgeois, 1980). An organization reacts to both its internal structure and its external environment. Every country has its own institutional environments and organizational structures are molded from varying influences that arise in those institutional environments (Scott, 1987). Differences in environment are related to a number of elements, including geographic location, economic position, and genetic factors (Hofstede, 1980). Studies have shown that companies based in one country or society exhibit a different approach to strategic planning than organizations based in another location or cultural system (Shleifer \& Vishny, 1997). Because environment plays a significant role in influencing the way in which the organization develops and tackles its strategic planning, it is valuable to understand the strategic planning tools and techniques used by the organization in the region or countries in which it exists.

Most of the research that exists related to strategic planning has been undertaken in developed countries and there is a visible lack of research on the topic in developing countries. Strategic planning research is a vast topic and has remained a popular field in management research until this day. It is also a field highly relevant to the business world, and organizations never cease to be interested in relevant academic findings. While numerous studies on strategic planning have been undertaken in developed countries such as the United States, Australia, Canada, Japan, the Netherlands, Singapore, and the United Kingdom, only very recently have research studies been conducted in developing regions such as the Arabian Gulf, Bahrain, Jordan, Saudi Arabia, and the United Arab Emirates (UAE) (Aldehayyat, Al Khattab, \& Anchor, 2011; Attahir \& Saffu, 2009; Elbanna, 2010; Ghamadi, 2005).

\section{Research Design}

The main objective of this study was to understand the nature and extent of strategic planning practices in organizations operating in the Sultanate of Oman. Survey research was adopted for this study because this research is the first of its kind in Oman.

The questionnaire for this study was adopted from Elbanna (2010). The questionnaire comprised three parts. The main questionnaire to be filled out by the respondent was composed of two parts with a final section including supporting information for the reference of respondents. The first sets of questions related to the respondents' basic information and the organization's background. The second sets of queries related to the strategic plan and extent to which planning tools and techniques were used. The 14 most commonly used strategic planning tools were chosen to estimate the frequency of usage. The third part contained reference information, including the basic definition of strategic planning and information on planning tools, to enhance the understanding of respondent. This effort was intended to put the respondents at the same level of understanding and comprehension of terms.

Several definitions of strategic planning exist, but for the purpose of this paper and to ensure consistency of responses across the sample organizations, we adopted the definition used by Elbanna (2010): "the development of a long-range written plan which covers more than one year for the effective management of environmental opportunities and threats, in the light of the organization's strengths and weaknesses. It should include formulating an organization's mission and/or vision, specifying long-term objectives and developing strategies which the organization plans to use to achieve these objectives." This definition of stratetegic planning was included in the questionnaire sent to respondents to avoid various interpretations of the term.

\subsection{Sample Size and Response Rate}

The final sample constituted 20 organizations in Oman. Due to the nature of the study, only organizations that had a written strategic plan were included in the sample. Sixty-three questionnaires were distributed to randomly chosen organizations in Oman and the total number of questionnaires filled out by respondents was 29. Of the completed questionnaires, four were unusable because of incomplete or inaccurate information, and five of the organizations did not have a written strategic plan and were not included in the sample. The overall response rate was $43 \% ; 32 \%$ of the questionnaires was considered usable for the study at hand, but $54 \%$ of the questionnaires was not returned and $14 \%$ was unusable.

The sample population segments included divisions by nature, sector, company size based on number of 
employees, business type, and operating zone. According to the nature of the companies, the sample consisted of $25 \%$ public, $60 \%$ private, and $15 \%$ semi-private companies. Based on the sector distribution, the sample population included 15\% manufacturing sector, $15 \%$ financial sector, and $70 \%$ other service sector. The service sectors included contracting and trading, education and training, consultation, tourism, entertainment, information technology (IT), transportation, and media and communication companies. The sample population comprised $65 \%$ large companies with more than 50 employees and 35\% small companies with fewer than 50 employees. According to ownership type, the sample population under study contained $25 \%$ single- and family-ownership firms, $15 \%$ business groups, $25 \%$ joint ventures, and $30 \%$ other ownership types. Sixty percent of the sample organizations operated inside the country and remaining $40 \%$ operated inside and outside Oman.

Considering the nature of the study, the data were collected from heads of departments and sections, directors, managers, and advisors directly involved in the strategic planning process. Of the respondents, $40 \%$ was female and $60 \%$ was male.

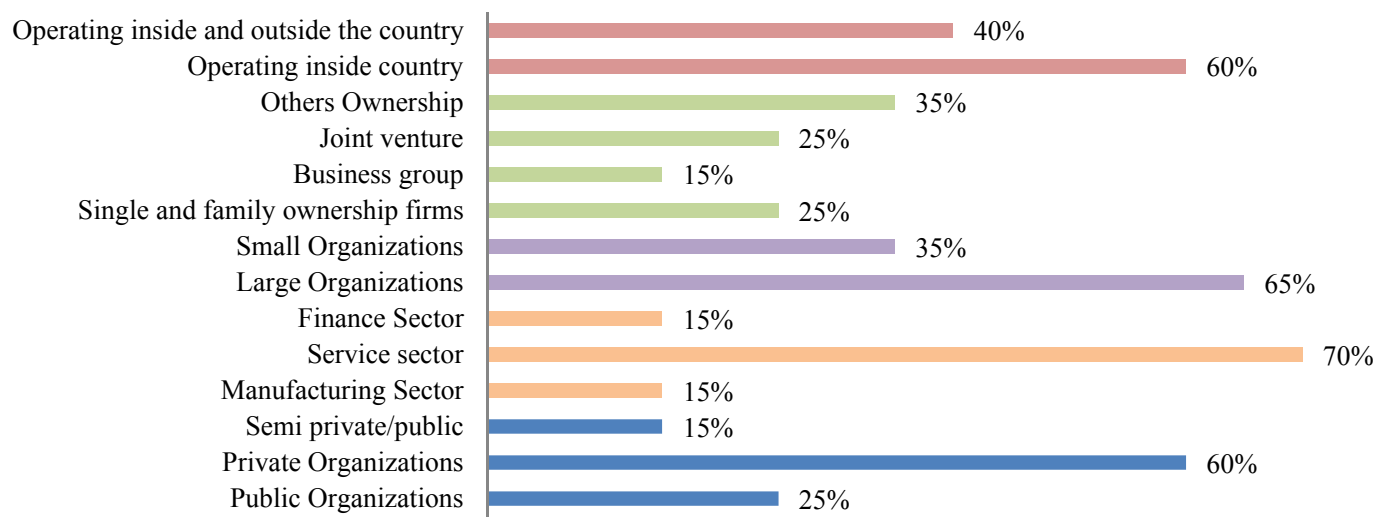

Figure 1. Percentage sample of companies in Oman—division based on nature, sector, size, type, and operating zone

\section{Analysis and Discussion}

Management research places strategic planning at the center of organizational practices and processes. Business strategy remains an essential part of an organization and strategic planning is the most popular instrument of strategic management (Rigby, 1999). During the 1950s, SWOT analysis was in trend and a well-used strategic planning tool. During the 1960s, more quantitative and qualitative tools were employed. In the 1980s, strategic planning tools and techniques of the shareholder value model and Porter's model were widely used. With more competition, organizations evolved and, to attain competitive advantage as well as survive, gave birth to a number of strategic planning tools and techniques (Gouillart, 1995). Researchers have outlined a number of existing strategic planning tools and techniques (Webster, Reif, \& Bracker, 1989). Selective strategic planning tools and techniques, 14 in number, have been employed in this study to understand the level and extent of their use in the region of Oman. Table 1 shows the frequency of usage of each strategic planning tools and techniques by organizations in Oman.

\subsection{SWOT Analysis (SWOT Analysis)}

SWOT analysis is a strategic planning method used to evaluate strengths, limitations, opportunities, and threats. The strengths, weaknesses, threats and opportunities are evaluated through systematic development of past, present, and future data. This involves specifying the objectives and identifying internal and external factors that are favorable and unfavorable for achieving the objective (Weihrich, 1982).

It is apparent from Figure 2 that the financial sector is utilizing the tool most frequently. It appears that a high percentage of organizations in Oman (i.e., nearly $60 \%$ of each segment) uses the tool quite commonly (frequently or very frequently). Looking at various organizational segments, the analysis shows that on average $28 \%$ of organizations in Oman use SWOT analysis, and 38\% use it frequently. Only $24 \%$ of organizations are not using or rarely using the technique. 


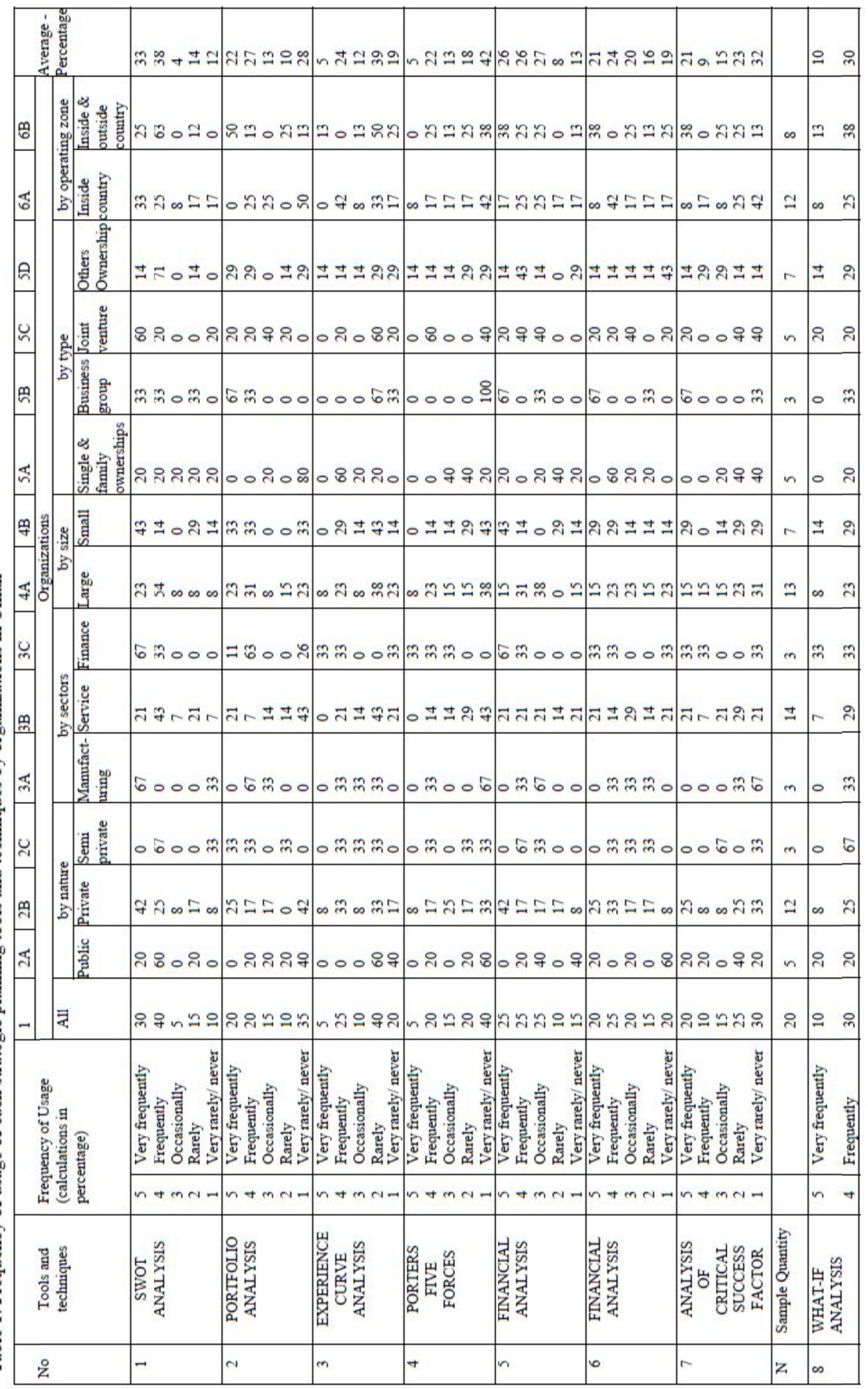




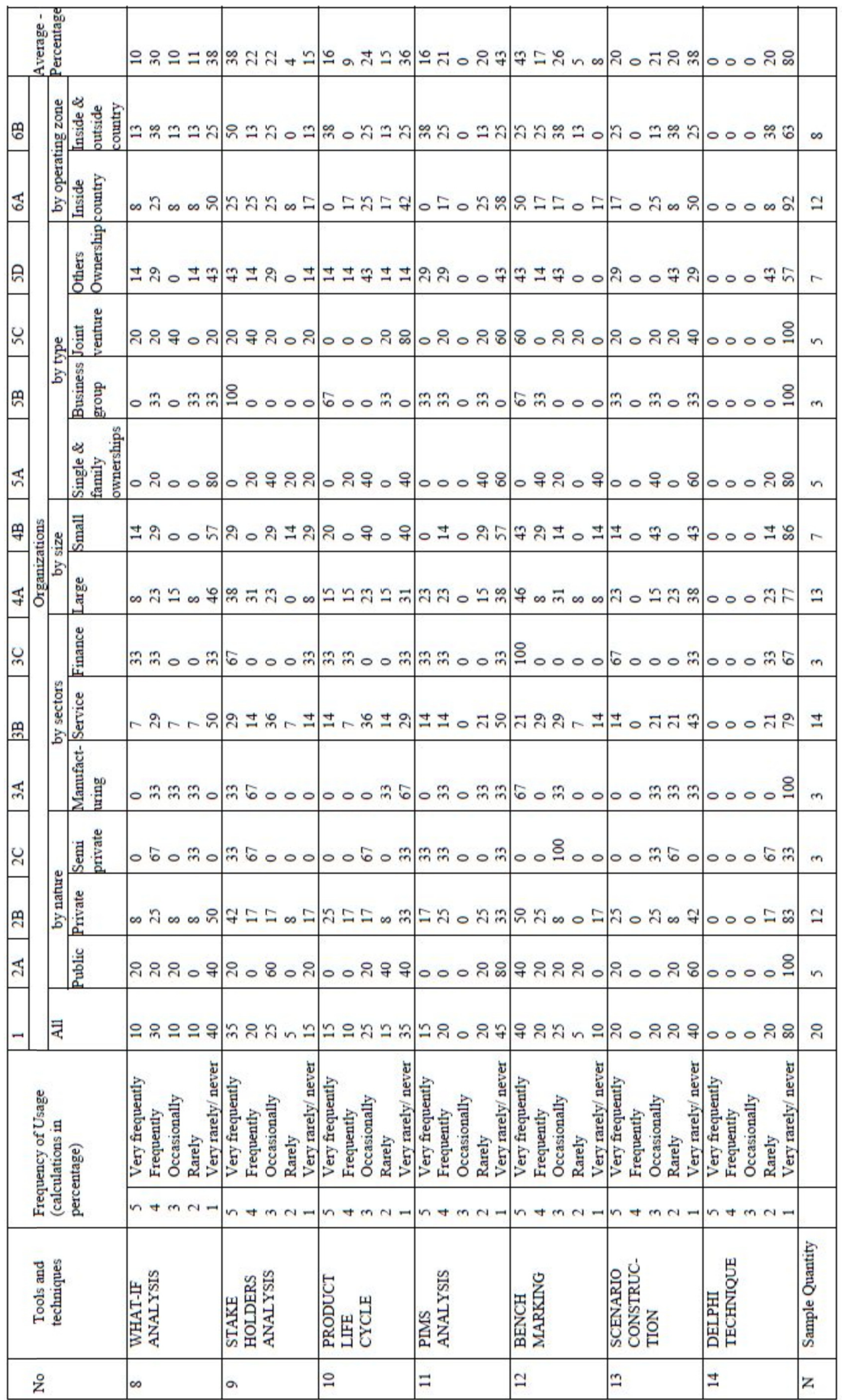




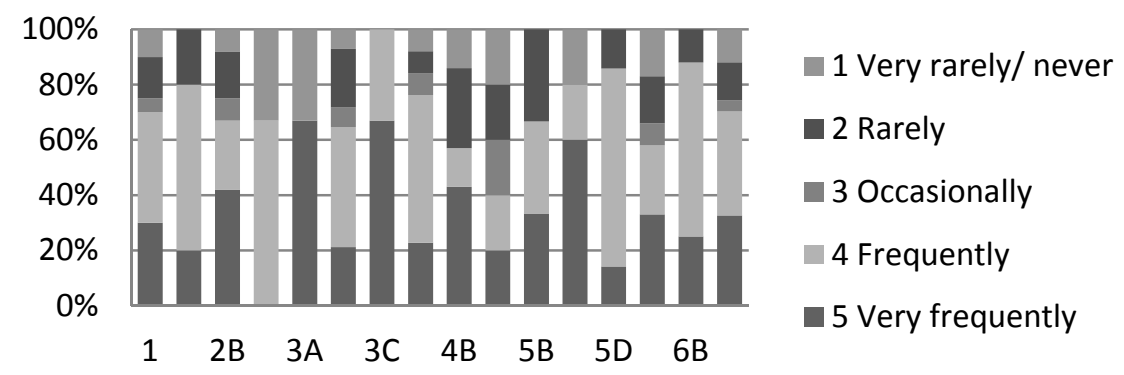

Figure 2. SWOT analysis

\subsection{Portfolio Analysis (BCG; Growth-Share Matrix and Directional Policy Matrix)}

Portfolio analysis is an organized way to analyze the products and services that constitute an organization's business portfolio. The two best-known portfolio planning methods are the growth-share matrix (BCG) from the Boston Consulting Group (BCG; Day, 1985) and the directional policy matrix (DPM) from General Electric/Shell (Robinson, Hichens, \& Wade, 1978).

Business groups apply the technique of portfolio analysis most commonly and those with single or private ownership apply the technique most rarely. On average, almost $20 \%$ of the organizations use the portfolio analysis technique very frequently, $27 \%$ use it frequently, $13 \%$ apply it occasionally, $10 \%$ use the technique rarely, and $28 \%$ of organizations use it very rarely or do not apply it at all.

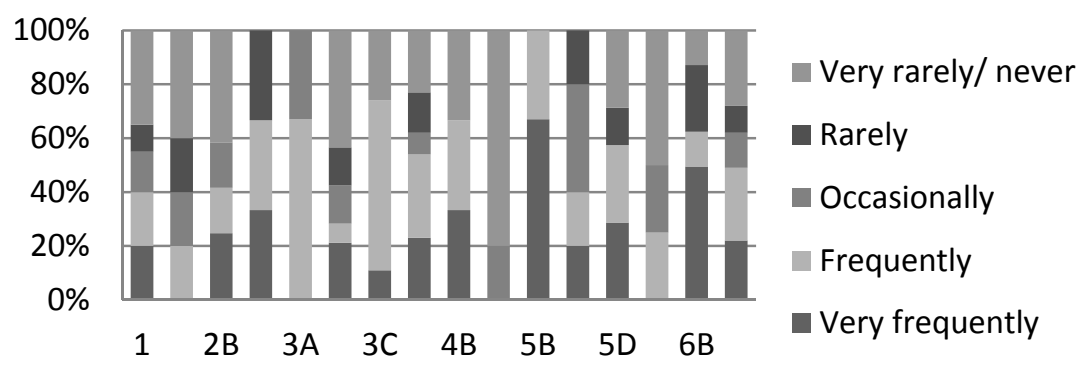

Figure 3. Portfolio analysis

\subsection{Experience Curve Analysis}

The experience curve is based on long-run strategic development, which is positioned on the idea that the more we do something, the easier it is to do and the more enhanced it becomes. Hence, the more experience gained by the passing of time to make a product or provide a service, the quicker and cheaper to achieve the outcome. The experience curve stresses the cost and price over an extended time for the company, product, and industry (Ghemawat, 1985; Neidell, 1983).

General observations from Figure 4 reveal that the experience curve analysis is least used by public organizations and business groups. The private, semi-private, financial, and manufacturing sectors use the tool more commonly. At least $20 \%$ of each segment applies the tool commonly (very frequently or frequently); exceptions include public organizations, business groups, and companies operating inside and outside Oman.

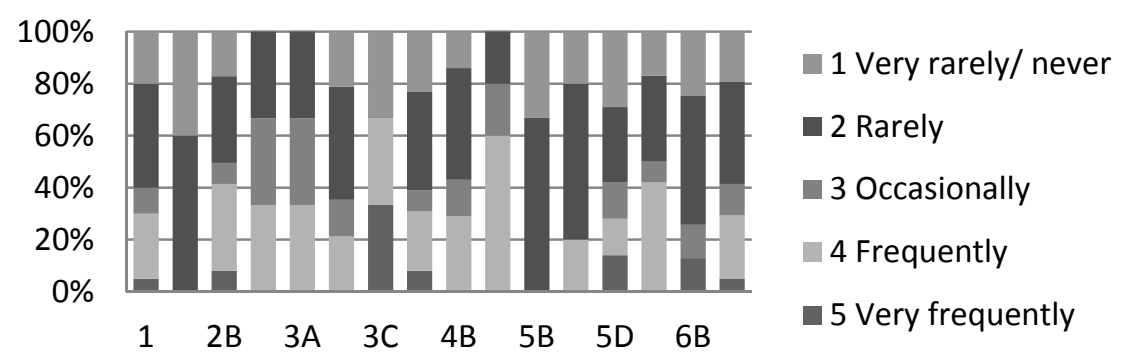

Figure 4. Experience curve analysis 
On average, the frequency of experience curve analysis is as follows: $5 \%$ of organizations uses it very frequently, $24 \%$ uses it regularly, and $12 \%$ uses it occasionally. However, a large number of firms (58\%) either uses it rarely or does not use it at all.

\subsection{Porter's Five Forces Analysis}

Primary determinants of the competitive strategy framework as identified by Porter's five forces in the industry are the threat of new entrants, the bargaining power of buyers, the threat of substitute products or services, the bargaining power of suppliers, and the rivalry among existing firms. The business strategy viewed in the context of this framework is to create a secure position in relation to competitive forces (Porter, 1983, 2008). The strength of these five forces collectively determines the basic potential of organizations to earn profits and survive. Each of the five forces has further underlying elements in a specific industry, which constitute the industry structure (Porter, 2008).

One can see that the business group companies are using Porter's five forces analysis tool at a minimum. The financial sector uses it more commonly. At least half of each segment either uses the tool very rarely or does not use it at all, exceptions being private organizations, the financial sector, and joint venture firms. At least $30 \%$ (each) of semi-private organizations, the manufacturing sector, the financial sector, large organizations, and joint ventures uses the tool frequently.

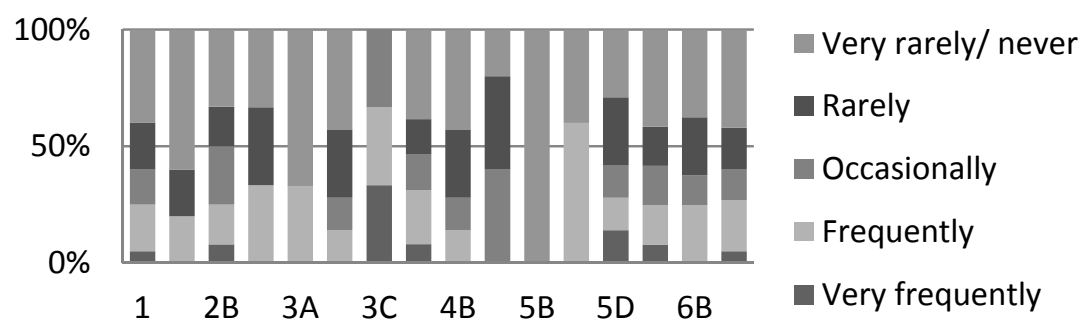

Figure 5. Porter's five forces analysis

On average, very frequent use of the tool is only $5 \% ; 22 \%$ of the organizations uses the tool frequently, $13 \%$ occasionally, $18 \%$ rarely, and almost $42 \%$ does not use it or uses it very rarely.

\subsection{Financial Analysis for Own Business}

Financial analysis can be applied in a wide variety of situations to provide the information needed to make critical decisions. Financial analysis involves utilizing historical data to gain information on the current and future financial health of a company (Donnahoe, 1989). Financial analysis is performed using ratio analyses and financial statements to assess the viability, profitability, and stability of the organization (Weston \& Brigham, 1975; Kristy, James, \& Susan, 1984).

From Figure 6, one can see that the financial sector in Oman is most commonly utilizing the financial analysis tool, while the single- and family-ownership group and public organizations use it the least. At least $60 \%$ of segments that use the financial analysis tool commonly (very frequently or frequently) is private organizations, semi-private firms, the financial sector, business groups, joint ventures, and other ownership firms. Taking the average percentage reveals that almost $26 \%$ of the organizations uses the tool very frequently, $26 \%$ uses it frequently, $27 \%$ occasionally, and $21 \%$ rarely or never.

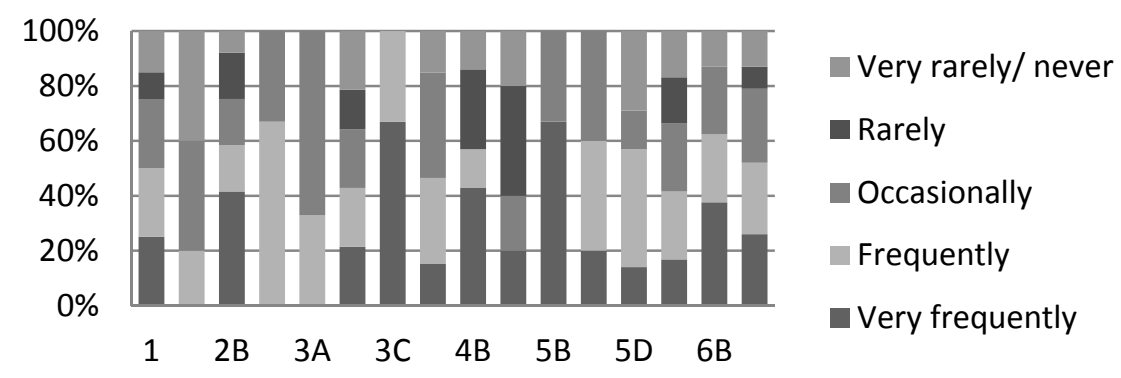

Figure 6. Financial analysis 


\subsection{Value Chain Analysis}

Porter developed the value chain to analyze customer need structures. The organization's value chain is demonstrated in the range of its activity stream, called the value system. Value chain analysis indicates that it is not sufficient to only study the company as a whole to understand its competitive advantage; rather, the competitive edge arises out of the multiple involved activities, including primary and support activities (Porter, 1985; Clark, Magretta, \& Carliss, 2000).

Figure 7 provides an overview of the situation, showing that value chain analysis is most frequently used by business groups. The tool is least used by government organizations and other ownership types. At least $20 \%$ of all segments uses the value chain analysis tool commonly (very frequently or frequently). Forty percent of all segments does not use it commonly (occasionally, rarely, or never), with the exception of the finance sector and business groups. On average, $21 \%$ of organizations uses the value analysis tool very frequently, $24 \%$ frequently, $20 \%$ occasionally, $16 \%$ rarely, and $19 \%$ very rarely or never.

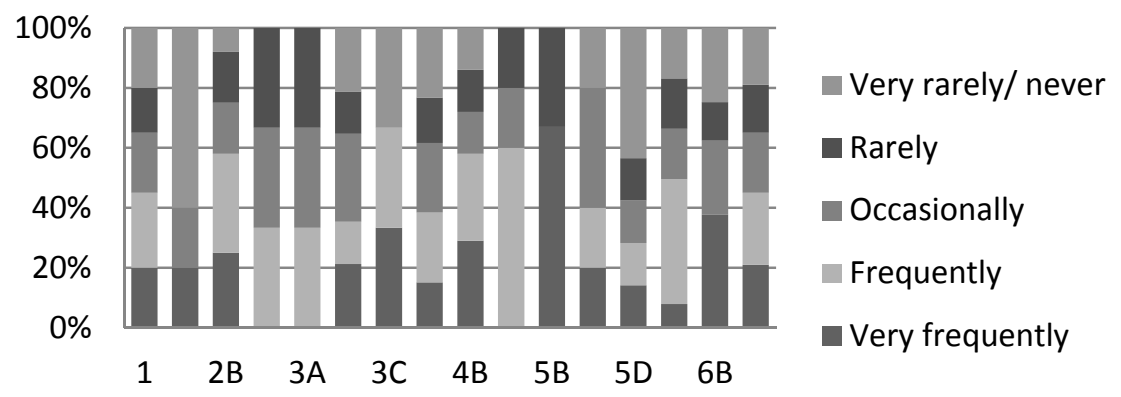

Figure 7. Value chain analysis

\subsection{Analysis of Critical (Key) Success Factors (CSFs)}

The concept of success factors has been applied and used in many sectors and organizations (Johnson \& Michael, 1995). To attain superior performance and success stability, an organization must achieve a few critical elements. Hence, identification and assessment of critical success factors becomes important to avoid pitfalls and attain smooth running of organizational activities for the organization's survival and success (Boynlon \& Zmud, 1984).

An overview reveals that manufacturing organizations, semi-private firms, and single-ownership firms use the tool least. There is minimal use of the tool seen in $45 \%$ and more of each segment, except the business group and the financial sector. At least $60 \%$ of the business and financial sectors uses the tool commonly. On average, $21 \%$ of organizations uses the critical success factor tool very frequently, $9 \%$ uses it frequently, $15 \%$ applies the tool occasionally, $23 \%$ utilizes this tool rarely, and $32 \%$ uses it very rarely or never.

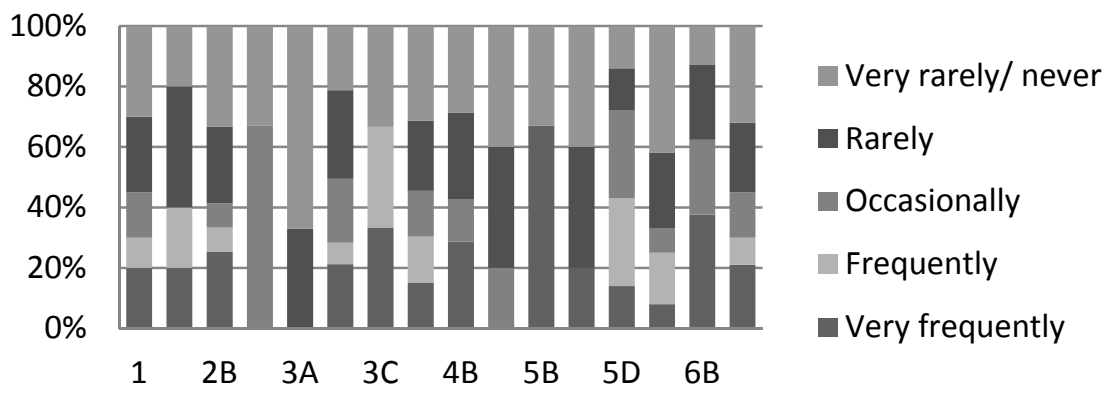

Figure 8. Analysis of critical success factors

\subsection{What-If Analysis}

What-if analysis is a method used to understand the outcomes and impacts of changes by systematically varying variables. What-if analysis allows the researcher to measure the effect of changing values of variables on the overall outcome (Philippakis, 1988). A few commercial tools are available that can assist in performing what-if analysis (Matteo, Stefano, \& Andrea, 2006). 
Figure 9 shows that single- and family-ownerships firms use the tool least commonly. At least $60 \%$ of all segments uses the tool on a limited basis, except for semi-private firms, financial firms, and the organizations that operate inside and outside Oman. Analysis shows that on average 10\% of the firms uses the tool very frequently, $30 \%$ uses it frequently, $10 \%$ applies it occasionally, $11 \%$ rarely, and $38 \%$ use it very rarely or never.

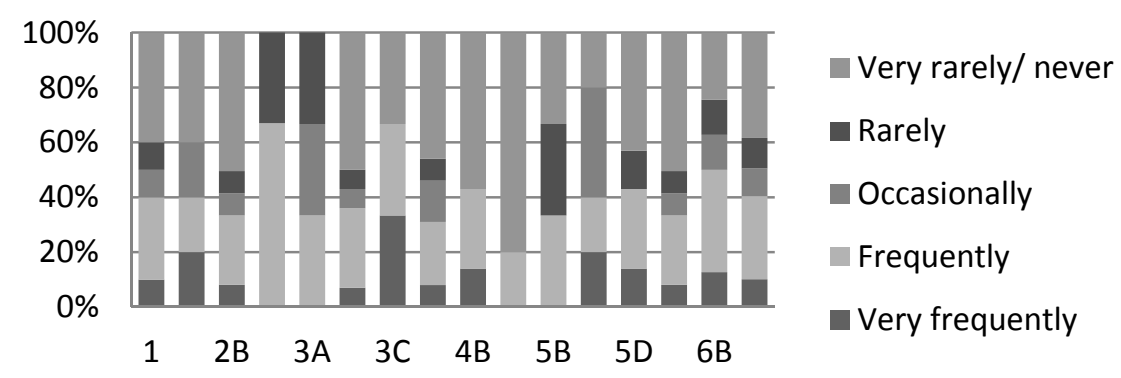

Figure 9. What-if analysis

\subsection{Stakeholders Analysis (Stakeholders Model)}

Stakeholders analysis identifies the important stakeholders, individual people and groups who influence the organization and its objectives (Freeman, 1984). The process includes evaluation and identification of stakeholders who are directly and indirectly affected by or can affect the organization's achievements and operations (Freeman, 1984).

An overview of the situation is shown in Figure 10; one can see that semi-private firms, industrial firms, and private firms use the tool most commonly. The tool is least used by single-ownership and family businesses. At least $20 \%$ of each sector uses the tool very frequently, with the exception of the single-ownership firms. Studying the average shows that $38 \%$ of the organizations uses the tool very frequently, $22 \%$ frequently, $22 \%$ occasionally, $4 \%$ rarely, and $15 \%$ either rarely or never.

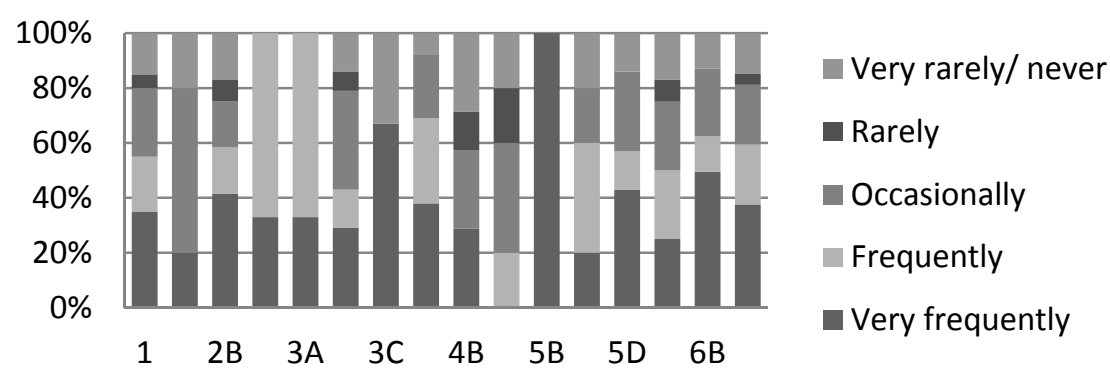

Figure 10. Stakeholder's analysis

\subsection{Product Life Cycle}

Product life cycle is a model for analysis based on the various successive stages in the development of an activity or product (Day, 1986; Lorange, 1980). The product life cycle is usually divided into five stages: launch, early growth, late growth, maturity, and decline (Steiner \& Miner, 1977).

Business groups are using the tool most commonly, followed by the financial sector companies that operate inside and outside Oman and private organizations. Surprisingly, it is least used by the industrial sector and joint ventures. The average percentage shows that almost $16 \%$ of the organizations uses the tool very frequently, $9 \%$ frequently, $24 \%$ occasionally, $15 \%$ rarely, and $36 \%$ very rarely or never. 


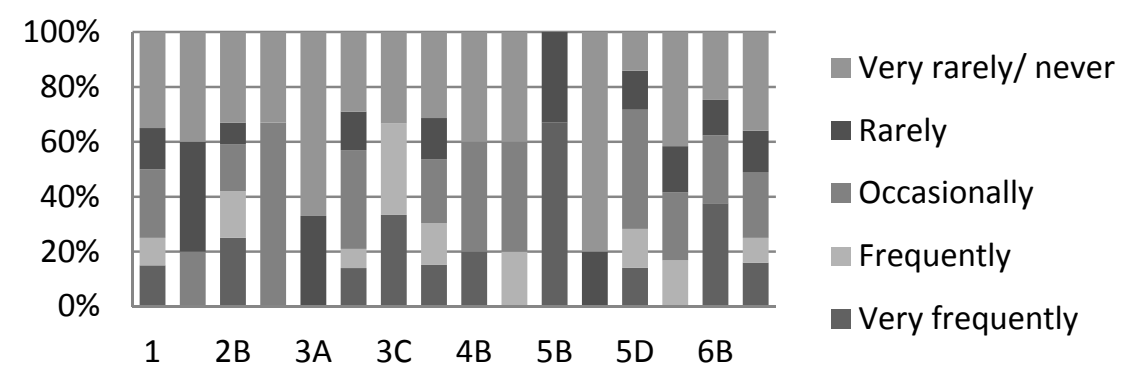

Figure 11. Product life cycle

\subsection{Profit Impact of Market Strategy}

Scholars have investigated the profit impact of market strategy (PIMS) due to its thorough analytical formation. PIMS is based on conclusions drawn from diversified samples collected over time (Schoeffler, Buzzell, \& Heany, 1974; Anderson \& Paine, 1978; Bradley \& Robert, 1987). It is a strategic planning tool that provides measures for business units in a diversified portfolio. It also attempts to create value in synergistic portfolios (Bradley \& Robert, 1987).

From Figure 12, one can see that the PIMS analysis tool is least commonly used by public organizations and single ownerships. At least $50 \%$ of each sector does not commonly use the tool, apart from five specific segments in organizations. The tool is most commonly used by semi-private firms, the finance sector, business groups, other ownership firms, and firms operating outside Oman (at least $60 \%$ of each utilizes the tool commonly). Large organizations use the tool more commonly than small organizations.

The results show that, on average, PIMS analysis is used in $16 \%$ of organizations very frequently and in $21 \%$ regularly. However, many firms (63\%) either use it rarely or do not use the tool.

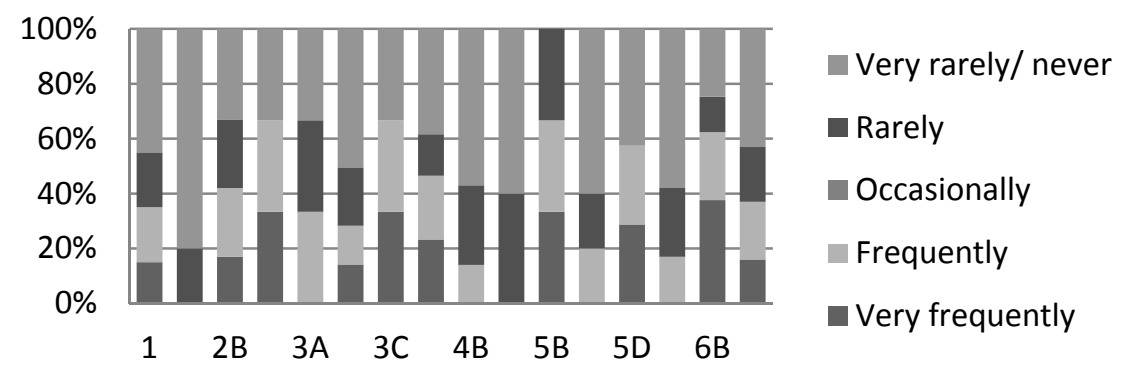

Figure 12. PIMS analysis

\subsection{Benchmarking}

Benchmarking was introduced as a way to measure progress (Bogan \& English, 1994; Karlof, Edenfelt, \& Marie, 2001). It is a comparative analysis method used to measure the organizational objectives and operations against other existing similar programs and strategic positions (Mennon \& Landers, 1987).

Note that the benchmarking tool shows that the benchmarking technique is very commonly used by organizations in Oman. At least $80 \%$ of each segment applies the benchmarking technique commonly or occasionally; the only exception is single- and family-ownership firms. The benchmarking technique is most frequently used by the financial sector.

On average, $43 \%$ of organizations uses the tool very frequently, $17 \%$ frequently, $26 \%$ occasionally, $5 \%$ rarely, and $8 \%$ very rarely or never. 


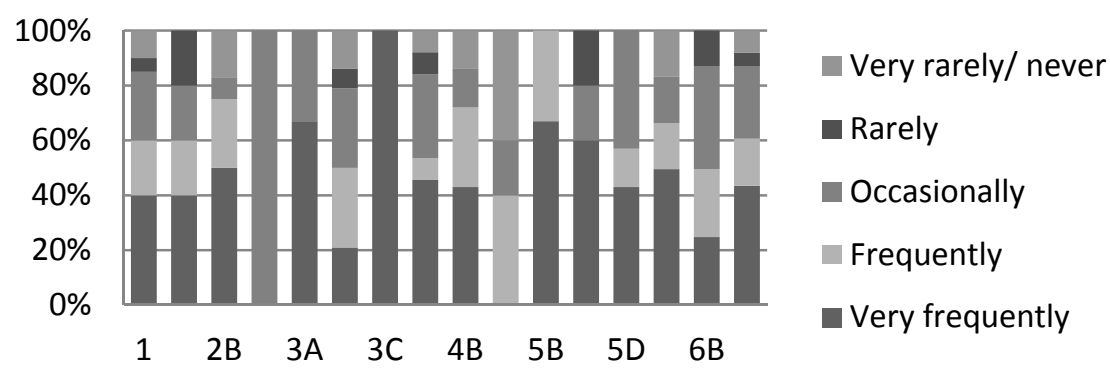

Figure 13. Bench marking

\subsection{Scenario Construction/Analysis}

Scenario analysis is used to forecast based on known trends and facts. It uses a description of a set of future situations through a sequence of time frames and snapshots. It helps in visualizing alternative courses of events based on a selection of assumptions and forecasts about future events (Nair \& Sarin, 1979). Scenario construction emerged as a useful tool to state possible lines of development and visualizations of alternative courses of actions on the basis of predictions and assumptions (Kees, 1996; Mats \& Hans, 2003; Peter, 1991).

Organizations in Oman do not commonly use scenario construction. At least $15 \%$ of each segment applies the tool more frequently, exceptions being semi-private firms, manufacturing firms, and single- or family-ownership organizations that apply the technique occasionally.

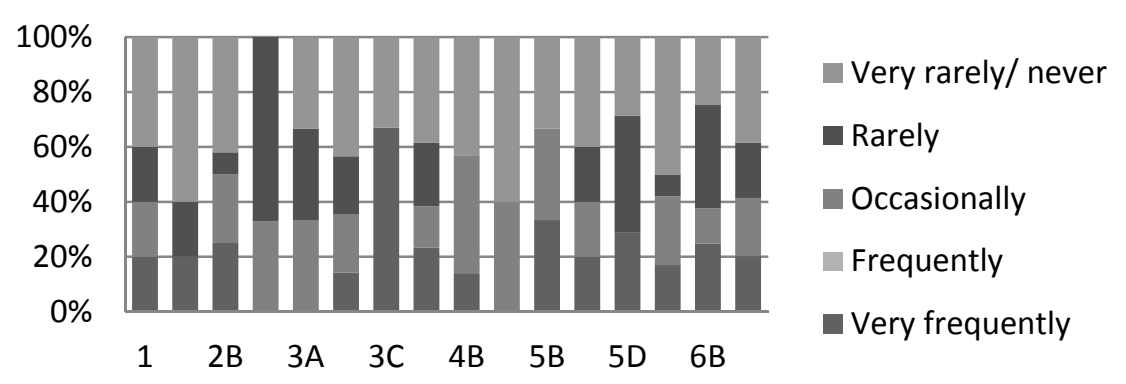

Figure 14. Scenario construction analysis

On average, almost $20 \%$ of the organizations uses scenario construction analysis very frequently and $20 \%$ applies it occasionally, while $20 \%$ uses the technique rarely and $40 \%$ uses it very rarely or does not apply it at all.

\subsection{Delphi Technique}

The Delphi method is based on the assumption that group judgments are more valid than individual judgments. It is a structured technique for gaining input and judgment from expert sources to address and solve problems (Harold \& Murray, 1975). A standard Delphi technique is developed as a systematic and interactive forecasting process that is carried out through a set of sequential questionnaires, combined with summarized information and feedback from earlier responses, to attain results (Rowe \& Wright, 1999; Delbeeq, Van de Ven, \& Gustafson, 1975).

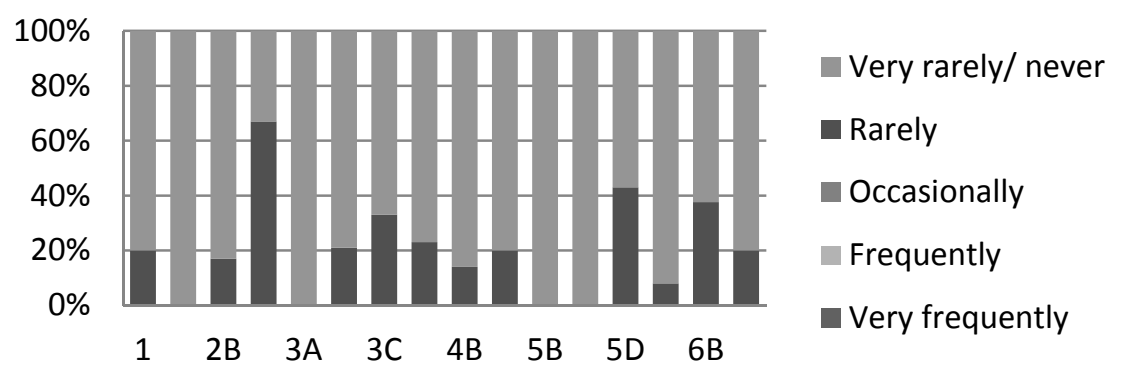

Figure 15. Delphi technique 
Simple analysis of the sample reveals that almost none of the firms in Oman uses the tool commonly, and almost all the firms use the Delphi technique rarely or have never used it. A more generalized view in Figure 15 shows that the Delphi technique is the least commonly used tool by the segments. All the segments either don't use the tool or use it rarely. From Table 1, one can see that on average $20 \%$ of the firms uses it rarely and $80 \%$ does not use the technique.

The most common strategic planning tools used by organizations in Oman are benchmarking, followed by stakeholders analysis and SWOT analysis. Financial analysis, portfolio analysis, value chain analysis, and critical success factors are used moderately. PIMS analysis, product life cycle, and scenario analysis have received limited use. The Delphi technique, experience curve, Porter's five forces, and what-if analysis techniques are the least commonly used strategic planning tools. Figure 16 and Figure 17 show the level of usage of the analyzed strategic planning tools employed by organizations in Oman.

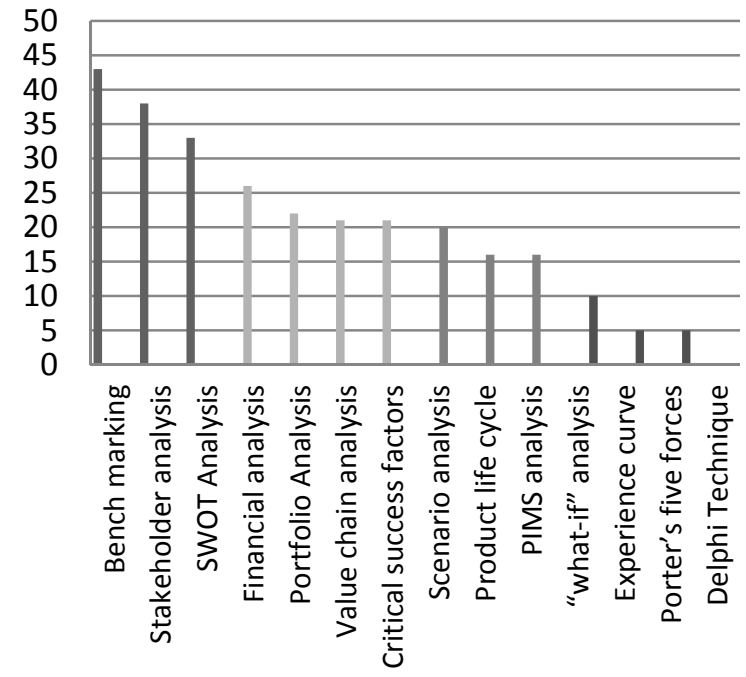

$$
\begin{aligned}
& \text { Most frequently used } \square \text { moderatly used } \\
& \text { rarely used } \\
& \text { Most rarely used }
\end{aligned}
$$
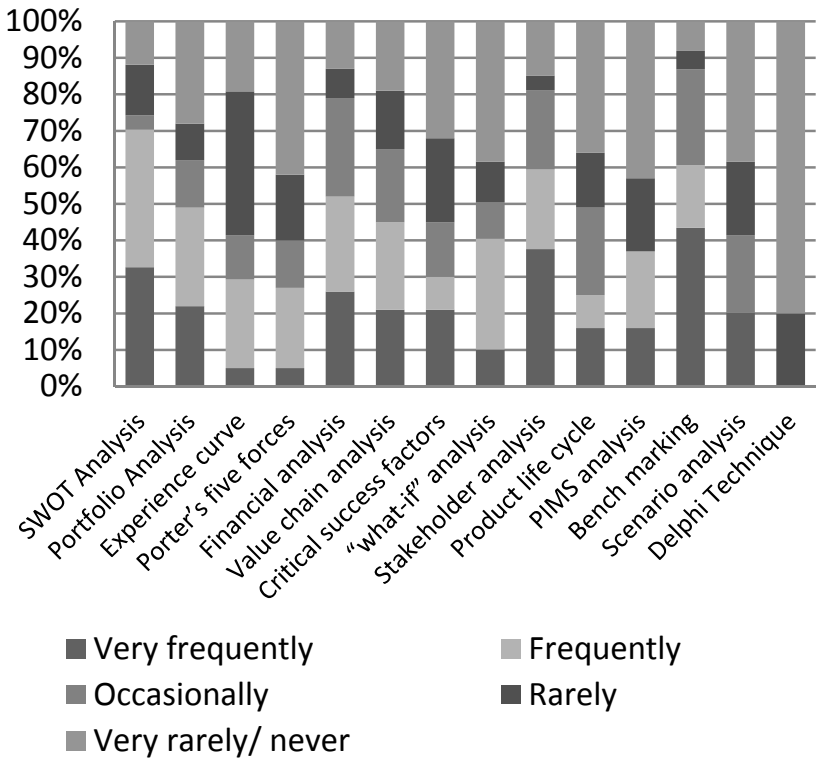

Figure 17. Results on strategic planning tools and techniques used by organizations in Oman

Furthermore, Table 2 shows average results for the tools' frequency of use by organizations in Oman. On average, $19 \%$ of organizations applies strategic planning tools very frequently, $19 \%$ frequently, $14 \%$ occasionally, and $15 \%$ rarely. Almost $30 \%$ of the organizations either uses the strategic planning tools very rarely or does not use them at all.

In comparison, the financial sector applies strategic planning tools very frequently, whereas the manufacturing sector shows the least usage of strategic planning tools. Looking at the size of organizations based on number of employees, the results show that large organizations use strategic planning tools more often than small organizations.

Analyzing the organizations based on business type, one can see that business groups use the tool more frequently, followed by other ownership types and joint ventures, whereas single and family ownerships use it most minimally. When comparing the companies according to their operating zones, it is apparent that companies with international operations use the tools more frequently than the companies that operate only inside Oman. Considering the nature of companies, one can see that private organizations are using strategic planning tools more frequently than semi-private organizations, which show moderate use, and public organizations apply limited strategic planning. 
Table 2. Average results: strategic planning tools and techniques

\begin{tabular}{|c|c|c|c|c|c|c|}
\hline \multirow[t]{3}{*}{ No } & \multirow[t]{3}{*}{ Strategic Planning tools and techniques } & \multicolumn{5}{|c|}{ Frequency of Usage in Percentage } \\
\hline & & 5 & 4 & 3 & 2 & 1 \\
\hline & & Very frequently & Frequently & Occasionally & Rarely & Very rarely/never \\
\hline 1 & SWOT Analysis & 33 & 38 & 4 & 14 & 12 \\
\hline 2 & Portfolio Analysis & 22 & 27 & 13 & 10 & 28 \\
\hline 3 & Experience curve & 5 & 24 & 12 & 39 & 19 \\
\hline 4 & Porter's five forces & 5 & 22 & 13 & 18 & 42 \\
\hline 5 & Financial analysis & 26 & 26 & 27 & 8 & 13 \\
\hline 6 & Value chain analysis & 21 & 24 & 20 & 16 & 19 \\
\hline 7 & Critical success factors & 21 & 9 & 15 & 23 & 32 \\
\hline 8 & "what-if" analysis & 10 & 30 & 10 & 11 & 38 \\
\hline 9 & Stakeholder analysis & 38 & 22 & 22 & 4 & 15 \\
\hline 10 & Product life cycle & 16 & 9 & 24 & 15 & 36 \\
\hline 11 & PIMS analysis & 16 & 21 & 0 & 20 & 43 \\
\hline 12 & Bench marking & 43 & 17 & 26 & 5 & 8 \\
\hline 13 & Scenario analysis & 20 & 0 & 21 & 20 & 38 \\
\hline \multirow[t]{2}{*}{14} & Delphi Technique & 0 & 0 & 0 & 20 & 80 \\
\hline & Average (Percentage) & 19 & 19 & 14 & 15 & 30 \\
\hline
\end{tabular}

Table 3. Average results_-all firms ad sectors

\begin{tabular}{|c|c|c|c|c|c|c|c|}
\hline \multirow[t]{3}{*}{ No } & \multirow[t]{3}{*}{ Organizations } & \multicolumn{6}{|c|}{ Frequency of Usage in Percentage } \\
\hline & & 5 & 4 & 3 & 2 & 1 & \\
\hline & & Very frequently & Frequently & Occasionally & Rarely & Very rarely/never & Quantity of sample \\
\hline 1 & All Organizations & 18 & 18 & 15 & 16 & 31 & 20 \\
\hline $2 \mathrm{~A}$ & Public Organizations & 11 & 12 & 14 & 18 & 42 & 5 \\
\hline $2 \mathrm{~B}$ & Private Organizations & 24 & 18 & 12 & 14 & 30 & 12 \\
\hline $2 \mathrm{C}$ & Semi private/public & 7 & 30 & 26 & 21 & 14 & 3 \\
\hline $3 \mathrm{~A}$ & Manufacturing Sector & 11 & 23 & 18 & 16 & 28 & 3 \\
\hline 3B & Service sector & 14 & 15 & 7 & 18 & 32 & 14 \\
\hline $3 \mathrm{C}$ & Finance Sector & 43 & 25 & 2 & 2 & 25 & 3 \\
\hline $4 \mathrm{~A}$ & Large Organizations & 18 & 21 & 15 & 14 & 29 & 13 \\
\hline 4B & Small Organizations & 21 & 14 & 13 & 16 & 34 & 7 \\
\hline $5 \mathrm{~A}$ & Single family ownership & 2 & 17 & 21 & 18 & 40 & 5 \\
\hline $5 \mathrm{~B}$ & Business group & 42 & 11 & 4 & 16 & 23 & 3 \\
\hline $5 \mathrm{C}$ & Joint venture & 18 & 18 & 15 & 14 & 32 & 5 \\
\hline $5 \mathrm{D}$ & Others Ownership & 20 & 22 & 14 & 14 & 37 & 12 \\
\hline $6 \mathrm{~A}$ & Operating inside country & 12 & 21 & 14 & 14 & 37 & 12 \\
\hline \multirow[t]{2}{*}{$6 \mathrm{~B}$} & $\begin{array}{l}\text { Operating inside \& outside the } \\
\text { country }\end{array}$ & 27 & 16 & 15 & 19 & 21 & 8 \\
\hline & Average (Percentage) & 19 & 19 & 14 & 15 & 30 & \\
\hline
\end{tabular}


Based on Table 3, $43 \%$ of the financial sector, $42 \%$ of business groups, and $27 \%$ of the organizations operating inside and outside Oman apply the tool most frequently, while $42 \%$ of public organizations, $40 \%$ of single-ownership and family businesses, $37 \%$ of companies operating inside Oman, and $34 \%$ of small organizations either don't use the tools or use them very rarely.

Figure 18 provides an overview of the frequency of usage of strategic planning tools by different segments. The financial sector and business groups use the tool most frequently whereas single- and family-ownership groups show limited use of strategic planning tools.

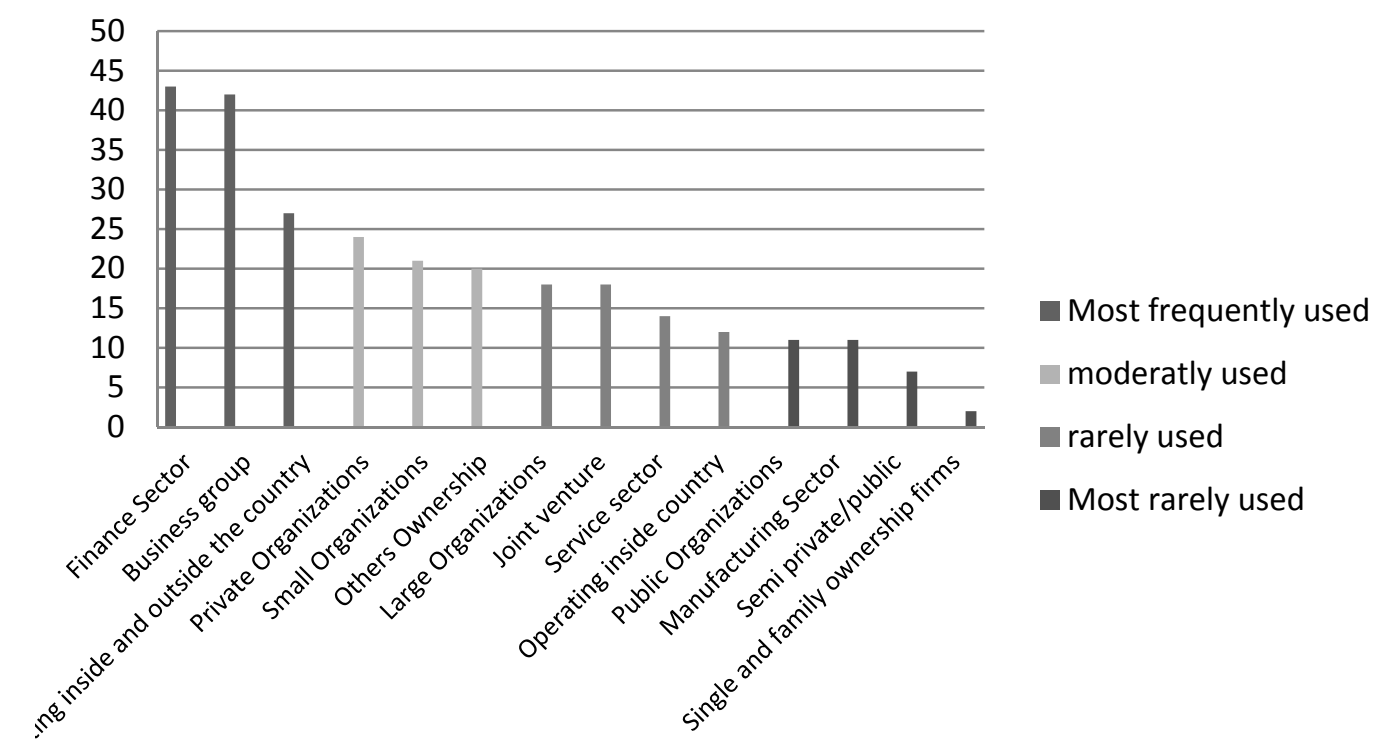

Figure 18. Level of strategic planning tools used by organizations in Oman based on nature, sector, size, type and operating zone

\section{Managerial Implications and Recommendations}

The extent of use of strategic planning tools in the organizations under investigation varies owing to the influence of a number of factors. The results of this study reveal a 'great divide' between the use of strategy tools and techniques and managers' awareness of the same. Managers are generally aware of most strategy tools and techniques, but they don't always use them to their optimal potential. Similarly, planning is a process that cannot be outsourced. Outside help can be brought in, but ultimately only the firm itself possesses enough inside knowledge to craft a strategy and take steps to achieve its goals. Based on our findings, managers must pay attention to the use of appropriate planning tools. Some authors have argued that each manager should have some level of understanding of strategic planning as it is associated with the management process and ultimately with the success of an organization (Mintzberg, 1979a; Steiner, 1979). Organizations should choose tools that support their strategic objectives (Rigby, 2001) and clearly communicate these tools to managers (Parson, 1934) to ensure successful implementation of the tools and fruitful outcomes. Top managers must obtain the essential experience and understanding to plan successfully, and the research provides fairly comprehensive information on the understanding and use of planning tools for managers in more regional contexts. Therefore, it is essential for the managers of these firms to augment their knowledge with regard to these techniques and their fitting use by attending specialized training courses and programs, thereby enhancing the strategic change process within their respective organizations.

Although this research contributes significantly to understanding the strategic planning tools used in Oman, it has two limitations. We only present the extent of planning tools used by firms in Oman. Further investigation is needed to identify the level of participation of employees at different organizational levels and to study the impact of the use of strategic planning tools on the success of organizations in Oman. Further research can be conducted to understand the significance of strategic planning procedures and results.

The paper does not explore the approaches used by organizations in Oman to implement each strategic planning 
tool, which allows for developing research questions that identify the methodologies organizations use to apply the management tools. Furthermore, this research could be measured for possibilities to study the quality of usage and application of strategic planning tools in our sample. Despite the limitations, this study provides a comprehensive understanding of the nature and extent of strategic planning practice in business organizations in the Sultanate of Oman.

\section{Conclusions, Implications, and Recommendations}

Although the established norm endorses the use of strategic planning tools as a vital cornerstone of the strategic planning process, strategy pundits have given little thought to the study of strategic planning tool usage. Instead, they have assimilated tool usage as a minuscule part of their investigations in both developed and emerging market contexts. In this paper, an attempt has been made to bridge the gap in the literature regarding this pivotal element of the strategic planning process by providing pertinent information about its use, awareness, and correlation with certain organizational facets.

This research indicates that although almost $30 \%$ of the firms very rarely or never uses strategic planning tools, organizations in Oman are utilizing strategic planning tools to some extent; they are moving beyond daily management and have started to plan for the future by using various types of strategic planning tools and techniques.

The paper provides an understanding of the level of use of strategic planning tools and related practices in various organizational sectors in the Sultanate of Oman. The literature suggests the importance, growing use of, and need for strategic planning for management purposes in organizations around the world. This study supplies the missing links in previous studies carried out on strategic planning and will also be a highly valuable reference for the future from local points of view. We set out to investigate the planning tools in a specific context to provide an understanding of the extent to which strategic planning tools are used in the region; the study can very well act as a future reference for organizations in a more local context.

\section{References}

Aldehayyat, J. S., Al Khattab, A. A., \& Anchor, J. R. (2011). The Use of Strategic Planning Tools and Techniques by Hotels in Jordan. Management Research Reveiw, 34(4), 477-490. http://dx.doi.org/10.1108/01409171111117898

Anderson, C., \& Paine, F. (1978). PIMS: A Reexamination. In W. A. (Ed.), Readings in Strategic Marketing. Chicago, IL: Dryden Press Ltd. http://dx.doi.org/10.2307/257549

Ansoff, H. (1965). Corporate Strategy. New York: McGraw Hill.

Ansoff, H. (1969). Business Strategy. Harmondsworth: Penguin.

Attahir, Y., \& Saffu, K. (2009). Planning practices, strategy types and firm performance in Arabian Gulf region. Education Business and Society:Contemporary Middle Eastern Issue, 2(3), 203-217.

Bogan, C. E., \& English, M. J. (1994). Benchmarking for best practices: winning through innovative adaptation. New York: McGraw Hill.

Bourgeois, L. J. (1984). Strategic management and determinism. Academy of Management Review, 9(4), 586-596. http://dx.doi.org/10.2307/258482

Bourgeois, L. J. (1980). Strategy and Environment: A Conceptual Integration. Academy of Management Review, 5(1), 25-39. http://dx.doi.org/10.2307/257802

Boynlon, A., \& Zmud, R. (1984). An Assessment of Critical Success Factors. Sloan Management Review, 25(4), $17-27$.

Bracker, J. S., \& Pearson, J. N. (1986). Planning and Financial Performance of Small Mature Firms. Strategic Management Journal, 53(7), 503-522. http://dx.doi.org/10.1002/smj.4250070603

Bradley, T., \& Robert, D. B. (1987). The PIMS Principles: Linking Strategy to Performance. New York: The Free Press.

Campbell, R. W., \& Garnett, J. L. (1989). Implementing strategy: Models and factors. In J. Rabin, G. J. Miller, \& W. B. (Eds.), Handbook of strategic management (pp. 257-278). New York: Marcel Dekker.

Clark, K. B., Magretta, J., Baldwin, C. Y., Dyer, J. H., \& Fisher, M. L. (2000). Harvard Business Review on Managing the Value Chain. Boston: Harvard Business School Press.

Cyert, R. M., \& March, J. (1956). A Behavioural Theory of the Firm. Prentice Hall. 
Day, G. (1986). Analysis for Strategic Market Decisions. St. Paul, MN: West Publishing Co.

Day, G. (1985). Diagnosing the Product Portfolio. In S. A. Ryans (Ed.), Strategic Planning: Concepts and Implementation. London: Random House Business Division.

De Wit, B., \& Meyer, B. (1998). Strategy: Process Content and Context (pp. 12-31).

Delbeeq, A., Van de Ven, A. H., \& Gustafson, D. (1975). Group Techniques for program planning: A guide to nominal group and Delphi processes. New York, Scott: Foreman and Company.

Donnahoe, A. S. (1989). What Every Manager Should Know about Financial Analysis. New York: Simon and Schuster.

Elbanna, S. (2008). Planning and Participation as Determinants of Strategic Planning Effectiveness. Management Decision, 46(5), 779-796. http://dx.doi.org/10.1108/00251740810873761

Elbanna, S. (2010). Strategic Planning in United Arab Emirates. International Journal of Commerce and Management, 26-40. http://dx.doi.org/10.1108/10569211011025934

Fayol, H. (1916) General and Industrial Management (pp. 4-6).

Freeman, R. (1984). Strategic Management. Boston: Pitman Publishing.

Galbraith, J. R., \& Kazanjian, R. K. (1986). Strategy implementation: Structure, systems and processes. St. Paul, MN: West Publishing Co.

Ghamadi, S. M. (2005). The use of Strategic Planning Tools and Techniques in Saudi Arabia: An Empirical Study. International Journal of Management, 22(3), 376-392.

Ghemawat, P. (1985 ). Building Strategy on the Experience Curve. Harvard Business Review.

Glaister, K. W., Dincer, O., Tatoglu, E., Demirbag, M., \& Zaim, S. ( 2008). A causal analysis of formal strategic planning and firm performance: Evidence from an emerging country. Management Decision, 46(3), 365-391. http://dx.doi.org/10.1108/00251740810863843

Gooderham, G. (1998). Debunking the myths of Strategic Planning. CMA magazine, 72(4), 164-171.

Gouillart, F. (1995). The day the music died. Journal of Business Strategy, 16(3), 14-20. http://dx.doi.org/10.1108/eb039697

Harold, A. L., \& Murray, T. (1975). The Delphi Method: Techniques and Applications. Mass: Adison Wesley.

Hart, S. (1992). An integrative framework for strategy-making processes. The Academy of Management Review, 17(2), 327-327. http://dx.doi.org/10.5465/AMR.1992.4279547

Hill, C. W., \& Jones, G. R. (1995). Strategic management an integrated approach. Boston: Houghton Mifflin Company.

Hofer, C. W., \& Schendel, D. E. (1978). Strategy Formulation Analytical Concepts.

Hofstede, G. (1980). Culture's Consequences: International Differences in Work-Related Values. Newbury Park, CA: Sage Publications.

Johnson, J. A., \& Michael, F. (1995). The Success Paradigm: Creating Organizational Effectiveness Through Quality and Strategy. New York: Quorum Books.

Karlof, B., Edenfelt, F., \& Marie, F. (2001). Benchlearning: Good Examples As a Lever for Development. United Kingdom: John Wiley and Sons Ltd.

Kees, V. D. (1996). Scenarios: The Art of Strategic Conversation. Chichester, England: John Wiley and Sons.

Kristy, J. E., \& Diamond, S. Z. (1984). Finance without Fear. New York: American Management Association.

Lorange, P. (1980). Corporate Planning: An Executive View Point. Englewood Cliffs, NJ: Prentice-Hall.

March, J. G., \& Simon, H. (1959). Organizations. USA: John Wiley \& Sons Inc.

Mats, L., \& Hans, B. (2003). Scenario planning: the link between future and strategy. New York: Palgrave Macmillan.

Matteo, G., Stefano, R., \& Andrea, P. (2006). Designing What-if Analysis: Towards a Methodology. ACM Workshop on Data Mining and OLAP 06 , 51-58.

Mennon, L., \& Landers, D. W. (1987). Advanced Techniques for Strategic analysis. Hinsdale, IL: The Dryden Press. 
Mintzberg, H. (1979a). The Structuring of Organizations: A Synthesis of the Research. Englewood Cliffs, NJ: Prentice Hall.

Mintzberg, H. (1994). The Rise and Fall of Strategic Planning. New York, NY: The Free Press.

Nair, K., \& Sarin, R. (1979). Generating Future Scenarios: Their Use in Strategic Planning. Long Range Planning, 12(3), 57-61.

Neidell, L. (1983). Don’t Forget the Product Life Cycle for Strategic Planning. Business, 30-35.

Olsen, J. B., \& Eadie. (1982). The game plan, governance with foresight. http://dx.doi.org/10.2307/976082

Parson, M., \& Culligan, M. (1934). Back to the Basics: Planning. Donnelly and Sons, 34-36.

Peter, S. (1991). The Art of the Long View: Planning for the Future in an Uncertain World. New York: Currency Doubleday.

Philippakis, A. S. (1988). Structured What if Analysis in DSS Models. HICSS (pp. 366-370). CA, USA: Society Press Los Alamitos.

Porter, M. E. (1985). Competitive Advantage: Creating and Sustaining Superior Performance. New York: Free Press.

Porter, M. E. (1980). Competitive Strategy: Techniques for Analyzing Industries and Competitors. New York: Free Press.

Porter, M. E. (1983). Industrial Organization and the Evolution of Concepts for Strategic Planning: The New Learning. Managerial and Decision Economics, 4(3), 172-172. http://dx.doi.org/10.1002/mde.4090040307

Porter, M. E. (2008). The Five Competitive Forces That Shape Strategy. Harvard Business Review, 86(1), 78-93.

Rhyne, L. C. (1986). The relationship of Strategic Planning to Financial performance. Strategic Management Journal, 7, 423-436. http://dx.doi.org/10.1002/smj.4250070504

Rigby, D. (1999). Management Tools and Techniques. Boston, MA: Bain and Company.

Rigby, D. (2001). Management tools and techniques: A survey. California Management Review, 43(2), 139-160. http://dx.doi.org/10.2307/41166079

Robinson, S., Hichens, R., \& Wade, D. (1978). The Directional Policy Matrix-Tool for Strategic Planning. Long Range Planning. http://dx.doi.org/10.1016/0024-6301(78)90045-6

Roush, C. H., \& Ball, B. C. (1980). Controlling the implementation of strategy. Managerial Planning, 29, 3-12.

Rowe, G., \& Wright, G. (1999). The Delphi technique as a forecasting tool: issues and analysis. International Journal of Forecasting, 15(4), 351-464. http://dx.doi.org/10.1016/S0169-2070(99)00018-7

Rowley, D. J. (1997). Strategic Change in Colleges and Unviversities. San Francisco, CA: Jossey-Bass Publishers.

Sarason, Y., \& Tegarden, L. F. (2003). The erosion of the competitive advantage of strategic planning: A configuration theory and resource based view. Journal of Business and Management, 1-20.

Schoeffler, S., Buzzell, R., \& Heany, D. (1974). Impact of Strategic Planning on Profit Performance. Harvard Business Review, 52, 37-45.

Scott, W. R. (1987). The Adolescence of Institutional Theory. Administrative Science Quarterly, 32(4), 493-511. http://dx.doi.org/10.2307/2392880

Shleifer, A., \& Vishny, R. W. (1997). A Survey of Corporate Governance. Journal of Finance, 52(2), 737-783. http://dx.doi.org/10.1111/j.1540-6261.1997.tb04820.x

Steiner, G. A. (1979). Strategic Planning: What Every Manager Must Know. New York: Free Press.

Steiner, G., \& Miner, J. (1977). Management Policy and Strategy. London: Macmillan Publishing Co.

Taylor, F. (1911). The Principles of Scientific Management (pp. 5-29). New York: Harper Bros.

Tung, R., \& Aycan, Z. (2008). Key Success Factors And Indigenous Management Practice in SMEs in emerging Ecconomies. Journal of World Web, 43, 337-381. http://dx.doi.org/10.1016/j.jwb.2008.04.001

Urwick, L. F. (1956). The Golden Book of Management. London: Newman Neame. 
Wall, S. J., \& Wall, S. R. (1995). The evolution (not the death) of strategy. Organizational Dynamics, 24(2), 6. http://dx.doi.org/10.1016/0090-2616(95)90068-3

Webster, L., Reif, W., \& Bracker, J. (1989). The Manager's Guide to Strategic Planning Tools and Techniques. Planning Reveiw, 4-13. http://dx.doi.org/10.1108/eb054273

Weihrich, H. (1982). The TOWS Matrix: A Tool for Situational Analysis. Long Range Planning, 15(2), 52-64. http://dx.doi.org/10.1016/0024-6301(82)90120-0

Weston, J. F., \& Brigham, E. F. (1975). Managerial Finance (5th ed.). Hinsdale, Illinois: The Dryden Press. http://dx.doi.org/10.2307/2330623

Yusuf, A., \& Saffu, K. (2009). Planning Practices, Strategy Types and Firm performance in Arabian Gulf Region. Contemporary Middle Eastern Issues, 2(3), 203-217. http://dx.doi.org/10.1108/17537980910981778

\section{Copyrights}

Copyright for this article is retained by the author(s), with first publication rights granted to the journal.

This is an open-access article distributed under the terms and conditions of the Creative Commons Attribution license (http://creativecommons.org/licenses/by/3.0/). 